Annals of the Rheumatic Diseases, 1986; 45, 82-84

Case report

\title{
Progressive proliferative glomerulonephritis in a patient with rheumatoid arthritis treated with D-penicillamine
}

\author{
A J WILLIAMS,${ }^{*} \mathrm{~J}$ N FORDHAM ${ }^{2}+\mathrm{C}$ G BARNES ${ }^{2}$ AND \\ F J GOODWIN
}

From the Departments of ${ }^{I}$ Nephrology and ${ }^{2}$ Rheumatology, The London Hospital, Whitechapel, London E1 $\stackrel{\infty}{N}^{\infty}$

SUMMARY A 49 year old man with rheumatoid arthritis developed a proliferative glomeru-פ্ّ lonephritis with progressive renal impairment during treatment with D-penicillamine. His renal function continued to deteriorate after the drug was stopped but improved after treatment with $₹$ corticosteroids and azathioprine.

Key words: renal failure, vasculitis, immune complexes.

Progressive renal impairment is not usually a feature of the renal lesions that may occur in patients treated with D-penicillamine. ${ }^{12}$ We report a patient with rheumatoid arthritis (RA) who developed a rapidly progressive proliferative glomerulonephritis during treatment with D-penicillamine.

\section{Case report}

A 49 year old man presented in 1981 with seropositive nodular RA. In June 1982 when his renal function and blood pressure were normal and antinuclear factor (ANF) and deoxyribose nucleic acid (DNA) binding tests negative he started treatment with D-penicillamine ( $250 \mathrm{mg}$ daily). The dose was increased in July to $250 \mathrm{mg}$ twice daily and again in October 1982 to $250 \mathrm{mg}$ three times daily. Proteinuria developed in November 1982 and persisted despite stopping D-penicillamine.

By January 1983 his blood pressure had risen to $170 / 115 \mathrm{mmHg}$, he had two small haemorrhages in

\footnotetext{
Accepted for publication 24 June 1985.

Correspondence to Dr F J Goodwin, Department of Nephrology, The London Hospital, Whitechapel, London, E1.

* Present address: The Renal Unit, Morriston Hospital, Swansea, West Glamorgan.

†Present address: Department of Rheumatology, Middlesbrough General Hospital, Middlesbrough, Cleveland.
}

his right optic fundus, and ankle oedema. Hiš๊ haemoglobin was $9 \cdot 2 \mathrm{~g} / \mathrm{dl}(92 \mathrm{~g} / \mathrm{l})$, leucocytes $6800 / \mu \stackrel{?}{\longrightarrow}$ $\left(6.8 \times 10^{9} / 1\right)$, and erythrocyte sedimentation rateo (ESR) $144 \mathrm{~mm} / 1 \mathrm{st} \mathrm{h}$. Plasma urea was $10 \mathrm{mmol} / \mathrm{P}$ and creatinine $190 \mu \mathrm{mol} / \mathrm{l}$. Latex test for rheumatoid factor was strongly positive (titre greater than 1 in 320 ), but the ANF was only weakly positive (titre 1/5). C3 $162 \mathrm{mg} / \mathrm{dl}(1620 \mathrm{mg} / \mathrm{l})$ - (normal range $650-1300 \mathrm{mg} / \mathrm{l})$ and C4 $62 \mathrm{mg} / \mathrm{dl}(620 \mathrm{mg} / \mathrm{l})$-(NRB $120-320 \mathrm{mg} / \mathrm{l}$ ) were raised. The $24 \mathrm{~h}$ urinary proteim was $12.5 \mathrm{~g}$. An electrocardiogram (ECG) showe ischaemic changes in the lateral chest leads. Renab biopsy showed diffuse glomerular lesions with en? docapillary cell swelling and occasional capsulan adhesions associated with focal sclerosis and reace tive extracapillary cell aggregates. In a few lesions collections of foam cells were seen within affected capillary loops, and one lesion showed localised tufu necrosis with deposited nuclear debris. Two small blood vessels were normal on light microscopy.

He was then treated with atenolol, hydralazine? spironolactone, and frusemide until his blood presse? ure was controlled, at which stage the hydralazine and spironolactone were stopped. During the nex 5 three months proteinuria (approx $5 \mathrm{~g} / 24 \mathrm{~h}$ ) persiste $\Phi^{\circ}$ and renal function deteriorated (Fig. 1). He de $\stackrel{\odot}{\oplus}$ veloped bilateral pleural effusions and widesprea\& retinal haemorrhages despite good control of his 


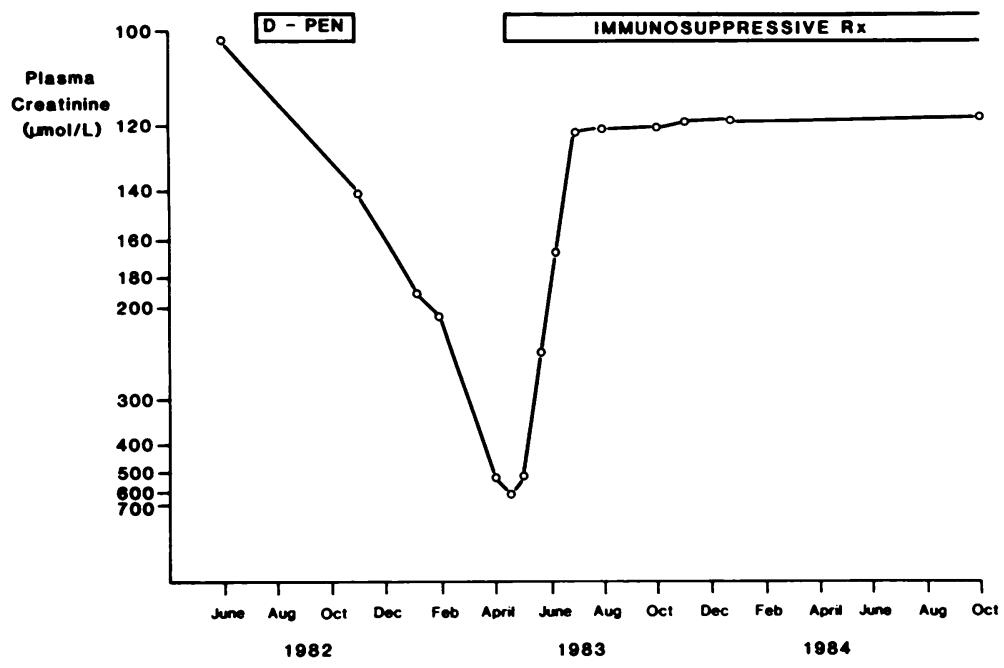

Fig. 1 Changes in plasma creatinine (reciprocal linear plot) during course of patient's illness.

blood pressure. ANF titre became strongly positive $(1 / 640)$, the DNA binding titre was slightly raised at $30 \mathrm{U} / \mathrm{ml}$ (NR 0-25), but the rheumatoid factor titre was unchanged. Serum $\mathrm{C} 3$ and $\mathrm{C} 4$ remained raised, and serum IgG was $188 \%$ of normal (NR $50-170$ g/l), IgM $1374 \%$ (NR 50-180 g/l), and IgA 675\% (NR $50-170 \mathrm{~g} / \mathrm{l}$ ). Immune complex assays (C1q binding, polyethylene glycol precipitation), were positive, and a skin biopsy showed a mixed perivascular and superficial infiltrate with $T$ cells in the dermis which stained diffusely for IgG. The epidermis showed a granular basement membrane fluorescence for IgM, IgA, and C3.

In April 1983 treatment was started with prednisolone (60 mg daily), azathioprine (100 mg daily), and dipyridamole (150 mg daily). Subsequently his general condition and renal function improved (Fig. 1), and the ECG reverted to normal. Immunoglobulin and complement levels returned to normal within three months and the ANF titre fell to $1 / 5$ by February 1984. The latex test for rheumatoid factor remained positive. The dose of prednisolone was gradually reduced and by October 1984 he was taking azathioprine ( $150 \mathrm{mg}$ daily) and prednisolone (10 mg daily). At that time, the plasma urea was 5.6 mmol/l, plasma creatinine $121 \mu \mathrm{mol} / \mathrm{l}$, and creatinine clearance $65 \mathrm{ml} / \mathrm{min}$. There was $0.9 \mathrm{~g}$ proteinuria per $24 \mathrm{~h}$.

\section{Discussion}

Patients with RA treated with D-penicillamine may develop proteinuria, which usually resolves when the drug is withdrawn. ${ }^{1}$ In most cases this is due to an immune complex mediated membranous nephropathy, which improves histologically as proteinuria diminishes and is not usually associated with progressive renal impairment. ${ }^{1-5}$

Proliferative glomerulonephritis is a rare complication of treatment with D-penicillamine. It was initially described in a patient with Wilson's disease ${ }^{6}$ but since then has occasionally been reported in patients with RA who have either developed a drug induced systemic lupus erythematosus syndrome (SLE) ${ }^{7}$ necrotising vasculitis, ${ }^{89}$ or Goodpasture's syndrome. ${ }^{10-12}$ Rarely it has been seen in patients with RA who have not developed features of additional systemic disease. ${ }^{13}$ Our patient is of interest in that he developed a proliferative glomerulonephritis leading to a progressive deterioration in renal function, which continued despite stopping D-penicillamine. He had many features of systemic disease with pleural effusions, ischaemic changes on his ECG, a raised ESR, and progressive retinal lesions despite blood pressure control, but he was atypical in several respects. In contrast with the few reported cases of drug induced SLE with renal impairment ${ }^{714}$ the ANF titre was low (1/5) and complement and immunoglobulin levels were high after renal function had started to deteriorate. It has been suggested that penicillamine induced SLE unlike other drug induced forms is associated with antibody to native DNA rather than single stranded or denatured $\mathrm{DNA}^{13}$ and that in this respect it is similar to the nephritis associated with spontaneously occurring SLE. For this reason it is not surprising that D-penicillamine induced SLE is sometimes associated with marked elevation of the 
DNA binding titre. ${ }^{15}$ In our patient we do not know whether the serological changes that subsequently occurred were due to D-penicillamine or hydralazine, but renal function had started to deteriorate and the renal biopsy was performed before treatment with hydralazine.

The widespread retinal haemorrhages that developed despite control of his blood pressure suggested a generalised vasculitis. However, he did not develop any of the cutaneous manifestations frequently described in patients with 'rheumatoid vasculitis', ${ }^{16}$ nor was there the involvement of medium sized vessels on renal biopsy that has been described in patients who have developed renal impairment with a necrotising vasculitis after treatment with D-penicillamine. ${ }^{89}$

The outcome of the few reported cases of proliferative glomerulonephritis that have been associated with D-penicillamine has been variable. When associated with drug induced $\mathrm{SLE}^{7}$ a good response has been noted on withdrawal of Dpenicillamine and treatment with steroids and cyclophosphamide. When associated with necrotising vasculitis the eventual outcome in those patients reported has been fatal despite treatment with steroids. ${ }^{89}$ In those cases in which acute proliferative glomerulonephritis has occurred in association with pulmonary haemorrhage but without the presence of antiglomerular basement membrane antibody, response to plasma exchange and immunosuppressive drugs has been reported, ${ }^{10}$ though other patients have progressed rapidly to end stage renal failure. ${ }^{11}$

Renal function in our patient continued to deteriorate for six months after stopping Dpenicillamine despite control of his blood pressure. At that stage he was given steroid therapy, azathioprine and dipyridamole, and it is probable that this played a major part in his recovery.

\section{References}

1 Bacon P A. Tribe C R. Mackenzic J C. Verrier Jones J, Cumming R H. Amer B. Penicillamine nephropathy in rheumatoid arthritis. $Q J$ Med 1976: 45: 661-84.

2 Huskisson E C. Renal diseases and penicillamine. Europ $J$ Rheumatol Inflamm 1979: 3: 156-4.

3 Ross J H. McGinty F. Brewer D G. Penicillamine nephropath! in rheumatoid arthritis. Nephron 1980: 26: 184-6.

4 Dische F E. Swinson D R. Hamilton E B D. Parsons $Y$. Immunopathology of penicillamine induced glomerular disease. $J$ Rheumatol 1976; 3: 145-54.

5 Neild G H. Gärtne: H V. Bohle A. Penicillamine induced membranous glomerulonephritis. Scand J Rheumatol 1979: (suppl 28): 79-90.

6 Adams D A. Goldman R. Maxwell M H. Latta H. Nephrotic syndrome associated with penicillamine therapy of Wilson:s disease. Am J Med 1964: 36: 331-6.

7 Chalmers A. Thompson D. Stein H E. Reid G. Patterson A C. Systemic lupus erythematosus during penicillaminc therapy for $\infty$ rheumatoid arthritis. Ann Intern Med 1982: 97: 659-63.

8 Banfi G. Imbasciati E. Guerra L. Mihatsch M J. Ponticelli C. 을 Extracapillary glomerulonephritis with necrotizing vasculitis in D-penicillamine treated rheumatoid arthritis. Nephron 1983:33: c 56-60).

9 Falck H M. Tornroth T. Kock B. Wegelius (O. Fatal renal vasculitis and minimal change glomerulonephritis complicating treatment with penicillamine. Acta Med Scand 1979: 205: 1,33-8.

10 Swainson C P. Thomson D. Short A I K. Winney R J. Plasma $\vec{C}$ exchange in the successful treatment of drug-induced renal disease. Nephron 1982; 30: 244-9.

11 Gibson T. Burry H C. Ogg C. Goodpasture's syndromc and Dpenicillamine. Ann Intern Med 1976: 84: 100-1

12 Hill H F H. Penicillamine in rheumatoid arthritis: adverse effects. Scand J Rheumatol 1979; (suppl 28): 94-9

13 Jaffe I A. References on penicillamine-induced renal disease. Ann Intern Med 1983: 98: 417

14 Bjorck S. Westberg G. Svalander C. Mulec H. Rapidl = progressive glomerulonephritis after hydralazine. Lancet 1983: ii: 42

15 Kirby J D. Dieppe P A. Huskisson E C. Smith B. D)Penicillamine and immune complex deposition. Ann Rheum Dis 1979: 38: 344-6.

16 Scott D G I. Bacon P A. Tribe C R. Systemic rheumatoid vasculitis: a clinical and laboratory study of 50 cases. Medicine (Baltimore) 1981: 60: 288-97.

17 Sternlieb I. Benett B. Scheinberg H. D-Penicillamine-induced Goodpasture's syndrome in Wilson : disease. Ann Intern Med 1975: 82: 673-6. 